\title{
Efek Oksigen Konsentrasi Tinggi Pascaoperasi Laparotomi pada Peritonitis terhadap Tingkat Infeksi Luka Operasi
}

\author{
Wildan Djaya, ${ }^{1}$ Reno Rudiman, ${ }^{2}$ Kiki Lukman ${ }^{2}$ \\ ${ }^{1}$ Rumah Sakit Bhayangkara Indramayu, ${ }^{2}$ Departemen Bedah Digestif Fakultas Kedokteran \\ Universitas Padjadjaran-Rumah Sakit Dr. Hasan Sadikin Bandung
}

\begin{abstract}
Abstrak
Metode sederhana untuk menambah tekanan oksigen secara adekuat pada perfusi jaringan yaitu dengan menambah konsentrasi oksigen yang diinspirasi pada penderita pascalaparotomi. Untuk melihat efektivitas oksigen konsentrasi tinggi tersebut dilakukan uji klinis di Rumah Sakit Dr. Hasan Sadikin Bandung. Dilakukan uji klinis secara random pada 102 penderita yang menjalani laparotomi karena peritonitis lokal atau difus serta membagi penderita dalam dua grup masing-masing 51 penderita untuk mendapatkan oksigen $30 \%$ dan $80 \%$ selama 2 jam pascaoperasi. Oksigen 30\% didapat dari nasal kanul dengan oksigen 3 liter, sedangkan oksigen $80 \%$ diperoleh dari nonrebreathing mask dengan oksigen 10 liter. Penanganan anestesi dilakukan standar dan semua penderita mendapat antibiotik profilaksis. Dengan menggunakan protokol single blind, luka dievaluasi saat penderita pulang atau hari ke-7 jika masih dirawat dan 2 minggu pascaoperasi. Uji klinis dilakukan di subbagian Bedah Digestif RSHS selama periode Oktober 2009-Mei 2010. Dari 51 penderita yang diberi oksigen 80\%, terdapat 2 (4\%) penderita mengalami infeksi luka operasi dibandingkan dengan 9 dari 51 penderita (18\%) yang diberi $30 \%$ oksigen. Durasi perawatan di rumah sakit sama pada kedua grup penderita. Simpulan, pemberian terapi oksigen konsentrasi tinggi pascaoperasi dapat menurunkan insidensi infeksi luka operasi. [MKB. 2012;44(3):165-9].
\end{abstract}

Kata kunci: Infeksi luka operasi, laparotomi, oksigen, peritonitis

\section{Effect of Laparotomy Post-Operative High Concentration Oxygen in Peritonitis to Surgical Wound Infection Level}

\begin{abstract}
A simple method to improve oxygen pressure to tissue perfusion adequately is by increasing the concentration of inspired oxygen. We therefore tested the hypothesis that the supplemental administration of oxygen during the post-operative period decreases the incidence of wound infection. We randomly assigned 102 patients at Dr. Hasan Sadikin Hospital who underwent exploratory laparotomy due to local and diffuse peritonitis to receive 30 percent or 80 percent inspired oxygen for two hours post-operation. The $30 \%$ oxygen was obtained from the nasal canule and 3 litres of oxygen whereas $80 \%$ oxygen was obtained from non-rebreathing mask and 10 litres of oxygen. Using the single-blind protocol, wounds were evaluated before the patients were discharged or 7 days post-operative and then two weeks after surgery. The clinical trial was performed at Dr. Hasan Sadikin Hospital Bandung between October 2009-May 2010. From the 51 patients who received 80\% oxygen, 2 (4\%) had surgicalwound infections, whereas from the 51 patients given 30 percent oxygen, $9(18 \%)$ had surgical-wound infections. The length of hospital stay for both groups were the same. In conclusion that post-operative administration of high concentration ofoxygen can reduce the incidence of surgical-wound infections. [MKB. 2012;44(3):165-9].
\end{abstract}

Key words: Laparotomy, oxygen, periotonitis, surgical wound infection

Korespondensi: Wildan Djaya, dr., Rumah Sakit Bhayangkara Indramayu, jalan Raya Pantura 73-75 Losarang Indramayu, mobile 08158055654, e-mail wildan_bedah@yahoo.com 


\section{Pendahuluan}

Infeksi luka operasi atau surgical site infection (SSI) masih menjadi penyebab penting dari angka morbiditas di Amerika Serikat. Data menunjukkan 27 juta penderita menjalani operasi setiap tahun, hampir 500.000 mengalami infeksi di sekitar luka operasi. Di Inggris tahun 2006 dilaporkan angka kejadian SSI sebesar $8,2-13,8 \%,{ }^{2}$ sementara di Australia tahun 2003 didapatkan angka kejadian SSI sekitar $2 \%$ sampai $13 \%{ }^{1}$

Analisis menunjukkan bahwa infeksi tersebut menyebabkan masa perawatan memanjang 7-9 hari dan menambah biaya lebih dari 3.000 dollar Amerika setiap infeksi luka operasi. Bahkan studi terbaru menunjukkan infeksi luka operasi menyebabkan masa perawatan memanjang ratarata dua minggu tiap penderita dan menambah biaya perawatan lebih dari 300 persen. ${ }^{3}$

Infeksi luka sebagai salah satu komplikasi tindakan operasi dapat timbul pada hari pertama hingga 1 tahun pascaoperasi, tetapi berdasarkan definisi yang dinamakan infeksi luka operasi yaitu infeksi yang timbul di daerah operasi hingga hari ke-30 atau dalam 1 tahun jika terpasang implan. ${ }^{4}$

Proses penyembuhan luka operasi memerlukan penghantaran oksigen yang adekuat. Luka yang mengalami iskemia sering kali sulit sembuh dan memiliki risiko yang sangat tinggi untuk terjadi infeksi. Iskemia sendiri biasanya terjadi karena beberapa faktor, antara lain penyakit penyumbatan pembuluh darah, vasokonstriksi, dan hipovolemia. Di samping itu, penjahitan luka yang terlalu tegang akan menyebabkan iskemia pada bagian luka dan terjadi gangguan penyembuhan luka. Sebaliknya, bila hantaran oksigen ke daerah luka meningkat akan merangsang proses penyembuhan luka yang lebih baik. Oleh karena itu, dapat disimpulkan perfusi jaringan memegang peranan penting pada penyembuhan luka, sehingga untuk mendapatkan penyembuhan luka yang baik harus dihindari faktor-faktor yang mengganggu perfusi jaringan.

Di Subbagian Bedah Digestif Departemen Bedah RS Dr. Hasan Sadikin Bandung tindakan bedah untuk peritonitis lokal dan umum dalam satu bulan dapat mencapai rata-rata lebih kurang 50 operasi, terdapat beberapa penderita yang mengalami infeksi luka operasi.

Suatu hipotesis menyatakan bahwa jikalau oksigenasi jaringan perioperatif baik maka dapat menurunkan angka infeksi luka operasi secara bermakna (angka kejadian infeksi luka operasi setelah oksigenasi dengan kadar lebih rendah $11,2 \%$, sedangkan kadar yang lebih tinggi $5,2 \%{ }^{5}$ Untuk itu penulis tergerak untuk meneliti efek pemberian terapi oksigen pascaoperasi dalam menurunkan infeksi luka operasi.

Tujuan penelitian ini untuk menganalisis perbedaan hasil pemberian oksigen $80 \%$ bila dibandingkan dengan oksigen 30\% sebagai salah satu cara untuk menurunkan angka kejadian infeksi luka operasi pada penderita yang telah dilakukan laparotomi eksplorasi.

Dengan diketahuinya peranan oksigenasi pascaoperasi pada penderita peritonitis lokal dan umum yang menjalani laparotomi eksplorasi dapat dijadikan salah cara untuk menurunkan angka infeksi luka operasi. Hal ini dapat menambah efisiensi baik dari segi waktu maupun biaya perawatan penderita pascaoperasi.

\section{Metode}

Bahan yang digunakan berupa data penderita yang berisi identitas, lembar observasi, dan data rekam medis. Subjek penelitian ini penderita peritonitis lokal atau umum yang telah menjalani tindakan operasi laparotomi eksplorasi di subbagian Bedah Digestif Departemen Bedah Rumah Sakit Dr. Hasan Sadikin (RSHS) Bandung selama periode bulan Oktober 2009-Mei 2010 dan bersedia mengikuti prosedur. Sebagai kriteria inklusi pada penelitian ini yaitu penderita peritonitis lokal atau umum yang berobat ke RSHS dalam kurun waktu penelitian, penderita dengan status gizi baik (indeks massa tubuh:18,5-24,9). Kriteria eksklusi albumin $<3,3 \mathrm{~g} / \mathrm{dL}$, leukosit $<2.500$ $\mathrm{sel} / \mathrm{m}^{3}$ atau $>20.000 \mathrm{sel} / \mathrm{m}^{3}$, sepsis berat, riwayat diabetes melitus, terdapat gangguan sistem imun, kelainan paru, obesitas, lama operasi lebih dari 4 jam, dan Hb kurang dari $10 \mathrm{~g} / \mathrm{dL}$.

Data identitas penderita dari rekam medis berupa usia, jenis kelamin, dan riwayat penyakit kronik (yang diperoleh dari alo dan heteroanamnesis), serta keadaan luka operasi selama penderita kontrol.

Penelitian ini mempergunakan uji diagnostik randomized control trial dengan consecutive sampling. Variabel bebas berupa pemberian oksigen $30 \%$ dan $80 \%$, sedangkan variabel tergantung yaitu infeksi luka operasi secara klinis.

Analisis statistik menggunakan statistical package for the social sciences (SPSS) 12.0 for Windows. Berdasarkan jenis data variabel bebas dan terikat dalam bentuk kategorik maka uji statistik yang digunakan chi-kuadrat dengan derajat kepercayaan 95\%.

\section{Hasil}

Dalam penelitian ini didapatkan 102 penderita yang memenuhi kriteria penelitian.Usia rata-rata subjek 31,07 tahun dengan usia paling muda 14 tahun dan paling tua 65 tahun, sebagian besar pada kelompok usia 21-30 tahun (Tabel 1). 
Tabel 1 Karakteristik Subjek Penelitian berdasarkan usia dan Jenis Kelamin Pederita Laparotomi Eksplorasi

\begin{tabular}{lc}
\hline Karakteristik & $\mathbf{n}$ \\
\hline Usia (tahun) & \\
Rata-rata (SB) & $31,07(12,43)$ \\
Median (Rentang) & $28,50(14-65)$ \\
$\leq 20$ & $27(26,5 \%)$ \\
$21-30$ & $30(29,4 \%)$ \\
$31-40$ & $23(22,5 \%)$ \\
$41-50$ & $11(10,8 \%)$ \\
$51-60$ & $10(9,8 \%)$ \\
$61-70$ & $1(1,0 \%)$ \\
Jenis kelamin & \\
Laki-laki & $55(53,9 \%)$ \\
Perempuan & $47(46,1 \%)$ \\
\hline
\end{tabular}

Sebagian besar penderita (91 orang: 89,2\%) yang mengalami laparotomi eksplorasi tidak mengalami infeksi luka operasi, subjek penelitian yang mengalami infeksi luka operasi sebanyak 11 orang $(10,8 \%)$ (Tabel 3).

Hasil penelitian ini menunjukkan bahwa karakteristik subjek penelitian berdasarkan usia dan jenis kelamin adalah homogen $(p<0,05)$, sehingga dapat dianalisis lebih lanjut (Tabel 2).

Berdasarkan uji chi-kuadrat dengan derajat kepercayaan 95\% tidak terdapat perbedaan yang bermakna angka kejadian infeksi luka operasi berdasarkan usia dan jenis kelamin $(\mathrm{p}=0,225$ dan 0,551) (Tabel 3).

Kejadian infeksi luka operasi lebih sedikit pada pemberian oksigen $80 \%$ bila dibandingkan dengan pemberian oksigen $30 \%(\mathrm{p}=0,025)$ (Tabel 4).

Pemodelan menggunakan uji regresi logistik

Tabel 2 Karakteristik Subjek Penelitian berdasarkan Usia dan Jenis Kelamin pada Pemberian Oksigen $80 \%$ dan Oksigen $30 \%$

\begin{tabular}{|c|c|c|c|}
\hline \multirow[b]{2}{*}{ Variabel } & \multicolumn{2}{|c|}{ Pemberian Oksigen } & \multirow[b]{2}{*}{$\mathbf{p}$} \\
\hline & $\begin{array}{c}30 \% \\
(\mathrm{n}: 51)\end{array}$ & $\begin{array}{c}80 \% \\
(\mathrm{n}: 51)\end{array}$ & \\
\hline Usia (tahun) & & & $\left.0,060^{*}\right)$ \\
\hline$\leq 20$ & 12 & 15 & \\
\hline $21-30$ & 21 & 9 & \\
\hline $31-40$ & 12 & 11 & \\
\hline $41-50$ & 4 & 7 & \\
\hline $51-60$ & 2 & 8 & \\
\hline $61-70$ & 0 & 1 & \\
\hline Jenis kelamin & & & $\left.0,321^{*}\right)$ \\
\hline Laki-laki & 25 & 30 & \\
\hline Perempuan & 26 & 21 & \\
\hline
\end{tabular}

() Uji chi-kuadrat
Tabel 3 Infeksi Luka Operasi berdasarkan Usia dan Jenis Kelamin pada Penderita Laparotomi Eksplorasi

\begin{tabular}{cccc}
\hline & \multicolumn{2}{c}{$\begin{array}{c}\text { Kejadian Infeksi } \\
\text { Luka Operasi }\end{array}$} & \\
\cline { 2 - 3 } Variabel & $\begin{array}{c}\text { Infeksi } \\
(\mathbf{n = 1 1 )}\end{array}$ & $\begin{array}{c}\text { Tidak } \\
\text { Infeksi } \\
(\mathbf{n = 9 1 )}\end{array}$ & \\
\hline Usia (tahun) & & & $\left.0,225^{*}\right)$ \\
$\leq 20$ & 1 & 26 & \\
$21-30$ & 4 & 26 & \\
$31-40$ & 3 & 20 & \\
$41-50$ & 3 & 8 & \\
$51-60$ & 0 & 10 & \\
61-70 & 0 & 1 & \\
Jenis kelamin & & & $\left.0,551^{*}\right)$ \\
Laki-laki & 5 & 50 & \\
Perempuan & 6 & 41 & \\
${ }^{*}$ Uji chi-kuadrat & & &
\end{tabular}

multipel, pemberian oksigen $80 \%$ lebih baik dalam menurunkan angka kejadian infeksi luka operasi dibandingkan dengan pemberian oksigen $30 \%$ pada penderita yang mengalami laparotomi eksplorasi yang bermakna dengan $\mathrm{p}=0,041$ dan rasio prevalensi (RP) 5,25. Ini berarti pemberian oksigen $80 \%$ berpeluang 5,25 kali lebih besar menurunkan angka kejadian infeksi luka operasi dibandingkan dengan pemberian oksigen 30\% (Tabel 5).

Tabel 4 Perbandingan Kejadian Infeksi Luka Operasi antara Pemberian Oksigen $80 \%$ dan Oksigen 30\% pada Penderita Laparotomi Eksplorasi

\begin{tabular}{cccc}
\hline & \multicolumn{2}{c}{ Kejadian Infeksi Luka } & \\
\cline { 2 - 3 } $\begin{array}{c}\text { Pemberian } \\
\text { Oksigen }\end{array}$ & $\begin{array}{c}\text { Infeksi } \\
(\mathbf{n = 1 1 )}\end{array}$ & $\begin{array}{c}\text { Tidak } \\
\text { Infeksi } \\
(\mathbf{n = 9 1 )}\end{array}$ & \\
\hline $30 \%$ & $9(18 \%)$ & $42(82 \%)$ & 0,025 \\
$80 \%$ & $2(4 \%)$ & $49(96 \%)$ & 0,025 \\
\hline${ }^{*}$ Uji chi-kuadrat & & &
\end{tabular}

\section{Pembahasan}

Banyak cara yang dilakukan untuk mengurangi infeksi yang berasal dari eksogen (lingkungan kamar operasi dan pembedah) serta mikrob endogen berdasarkan profilaksis yang terdiri atas pemakaian cara mekanis, kimiawi, dan obat antimikrob, baik secara sendiri-sendiri maupun bersamaan. 
Tabel 5 Pemberian Oksigen $80 \%$ dan Oksigen 30\% berhubungan dengan Kejadian Infeksi Luka Operasi pada Penderita Laparotomi Eksplorasi dengan Mempertimbangkan Faktor Lain

\begin{tabular}{clcccc}
\hline Model & \multicolumn{1}{c}{ Variabel } & Koefisen $\boldsymbol{\beta}$ & SE & Nilai p & RP (95\% IK) \\
\hline Awal & & & & & \\
& Pemberian oksigen & 1,924 & 0,868 & 0,027 & $6,84(1,25-37,51)$ \\
& Usia & $-0,045$ & 0,030 & 0,127 & $0,96(0,90-1,01)$ \\
& Jenis kelamin & $-0,415$ & 0,684 & 0,544 & $0,66(0,17-2,52)$ \\
& Konstanta & 1,616 & & \\
Akhir & & & & \\
& Pemberian oksigen & 1,658 & 0,810 & 0,041 & $5,25(1,07-25,65)$ \\
& Konstanta & $-0,118$ & & & \\
\hline
\end{tabular}

${ }^{*}$ uji regresi logistik multipel

Pada penderita yang mengalami laparotomi eksplorasi, angka kejadian infeksi luka operasi lebih sedikit pada pemberian oksigen $80 \%$ bila dibandingkan dengan 30\%. Hal ini menunjukkan bahwa pemberian oksigen $80 \%$ lebih baik untuk menurunkan angka kejadian infeksi luka operasi dibandingkan dengan $30 \%$ pada penderita yang mengalami laparotomi eksplorasi.

Luka operasi akan mengalami kerusakan dari suplai darah lokal sebagai hasil perlukaan dan trombosis pembuluh darah yang menyebabkan luka menjadi hipoksia bila dibandingkan dengan jaringan normal. Tekanan oksigen pada luka sering $<30 \mathrm{mmHg}$. Hal ini dapat diperbaiki dengan menambah tekanan arterial oksigen. Tujuan utama terapi oksigen untuk dapat mencegah dan koreksi hipoksemia dan atau hipoksia jaringan. Pada kerusakan pembuluh darah kecil terjadi hipoksia relatif jaringan sekitar luka dengan tekanan ratarata $25 \mathrm{mmHg}$ di luka dan $40 \mathrm{mmHg}$ di jaringan normal.

Dalam penelitian ini penderita mendapat terapi yang sama sesuai standar RS Dr. Hasan Sadikin Bandung dalam hal mulai dari persiapan, antibiotik profilaksis, antiseptik, dan antibiotik postoperasi. Semua operasi dilakukan oleh dokter residen dan setelah sampai di ruangan tidak ada yang mendapat oksigen lagi sampai penderita pulang. Penggantian verban hanya dilakukan di poli Bedah Digestif RSHS saat penderita kontrol.

Sampel pada penelitian ini sebanyak 102 penderita, terdiri atas peritonitis lokal karena apendisitis perforasi 77 penderita, peritonitis difus karena apendisitis perforasi 15 penderita, dan peritonitis difus karena perforasi organ berongga 15 penderita. Penderita yang mengalami infeksi luka operasi 11 orang.

Pada penelitian ini diberikan oksigen selama 2 jam karena apabila terlalu lama diperkirakan akan timbul tanda-tanda intoksikasi oksigen, terutama oksigen $80 \%$. Dalam literatur dinyatakan bahwa gejala intoksikasi oksigen mulai timbul pada pemberian 8 jam, sehingga penulis mengambil batas yang relatif aman yaitu 2 jam. Penderita dirawat di ruang pemulihan biasanya tidak terlalu lama sampai dijemput untuk kembali ke ruangan, sehingga jika lebih dari 2 jam akan menyulitkan pelaksanaannya.

Bardasarkan hasil analisis statistik didapatkan angka kejadian infeksi pascaoperasi bermakna lebih rendah pada pemberian oksigen $80 \%(4 \%)$. Hasil ini lebih tinggi bila dibandingkan dengan penelitian Greif $\mathrm{dkk}^{5}$ yaitu penderita yang menjalani laparotomi eksplorasi karena kanker dan inflammatory bowel disease yang diberi oksigen $80 \%(5,2 \%)$ dan yang diberikan oksigen $30 \%(11,2 \%){ }^{5}$

Angka kejadian infeksi luka operasi yang lebih rendah tentu akan lebih menguntungkan karena mengurangi biaya pengobatan, lama rawat, serta kehilangan atau berkurangnya pendapatan akibat tidak masuk kerja.

Simpulan, pemberian terapi oksigen dengan konsentrasi tinggi (80\%) pascaoperasi dapat menurunkan insidensi infeksi luka operasi.

\section{Daftar Pustaka}

1. Surgical Site Infection Definition. Australia Infection Control Association; 2005 [diunduh 15 September 2007]. Tersedia dari http:// www.safetyandquality.gov.com.

2. Hunt TK, Hopf HW. Wound healing and wound infection. What surgeons and anesthesiologists can do. Surg Clin North Am. 1997;77(3):587-606.

3. Barnard B, Prevention of surgical site infection, New York, 2003. [diunduh 21 April 2009]. Tersedia dari: http://www. woundhealing.com.

4. Rhee $\mathrm{H}$, Bonnie $\mathrm{H}$, Reducing surgical site infection, Virginia, 2008 [diunduh 13 Mei 2009]. Tersedia dari: http://www. infectioncontroltoday.com/articles/2008/03/ reducing-surgical-site-infections.aspx. 
5. Greif R, Akça O, Horn EP, Kurz A, Sessler DI, Outcomes Research Group. Supplemental perioperative oxygen to reduce the incidence of surgical-wound infection. N Engl J Med. 2006;342(3):161-7.

6. Robert A. Wound care. Dalam: Thorne $\mathrm{CH}$, penyunting. Grabb and Smiths plastic surgery. Edisi ke-6. New York: Lippincott and Wilkins; 2007. hlm 23-31.

7. Lorenz P, Longaker M. Wound: biology, pathology and management. Dalam: Norton AJ, penyunting. Surgery basic science and clinical evidence, Philadelphia: Springer; 2001. hlm. 221-30.

8. Forrest APM. Skin, connective tissue and soft tissue. Dalam: Bland K, penyunting. Principles and practice of surgery. Philadelphia: Churchill Livingstone; 2001. hlm. 190-209.

9. Dunn DL. Surgical infection. Dalam: Schwartz SI, penyunting. Principles of surgery. Edisi ke-8. New York: Mc GrawHill Inc; 2005. hlm. 109-28.

10. Cherry GW. Wound healing. Dalam: Morris $\mathrm{AJ}$, penyunting. Oxford textbook of surgery. Oxford: University Press; 2004. hlm. 3-41.

11. Peacock E. The wound healing. Dalam:
Grabb W, penyunting. The art of aesthetic plastic surgery. New York: Little Brown and Company; 1999. hlm. 1109-20.

12. HICPAC and CDC recommendation for prevention of surgical infection, 2008

13. Mangram AJ, Horan TC, Pearson ML, Silver LC, Jarvis WR. Guideline for prevention of surgical site infection, 1999. Hospital Infection Control Practices Advisory Committee. 1999;20(4):250-78.

14. Supardi I. Prosedur bahan pemeriksaan laboratorium bakteriologi klinik. Bandung: Bagian Mikrobiologi FK Unpad; 2004.

15. Deitch EA. Tools of the trade and rules of the road of surgical guide. Philadelphia: Lippincot-Raven; 2002.

16. Morgan GE, Mikhail MS. Murray MJ. Clinical anesthesiology. New York: McGrawHill; 2009.

17. Jawetz E. Review of medical microbiology. Edisi ke-16. Los Altos California: Lange Medical Publication; 1999.

18. Dellinger RP, Levy MM, Carlet JM, Bion J, Parker MM, Jaeschke R, dkk. Surviving Sepsis Campaign: international guidelines for management of severe sepsis and septic shock: 2008. Intensive Care Med. 